\title{
Integrated effect of urea and poultry manure on growth, yield and postharvest quality of cucumber (Cucumis sativus L.)
}

\author{
Noosheen Zahid', Muhammad Jamil Ahmed ${ }^{1}$, Majid Mahmood Tahir ${ }^{2}$, Mehdi Maqbool ${ }^{*}$, \\ Syed Zulfiqar Ali Shah ${ }^{1}$, Sundas Jamshaid Hussain ${ }^{1}$, Abdul Khaliq ${ }^{2}$, Muhammad Ishaq Asif Rehmani ${ }^{3}$ \\ ${ }^{1}$ Department of Horticulture, Faculty of Agriculture, University of Poonch Rawalakot, Azad Jammu and Kashmir, Pakistan \\ ${ }^{2}$ Department of Soil and Environmental Sciences, Faculty of Agriculture, University of Poonch Rawalakot, Azad Jammu and \\ Kashmir, Pakistan \\ ${ }^{3}$ Department of Agronomy, Ghazi University, Dera Ghazi Khan, Pakistan
}

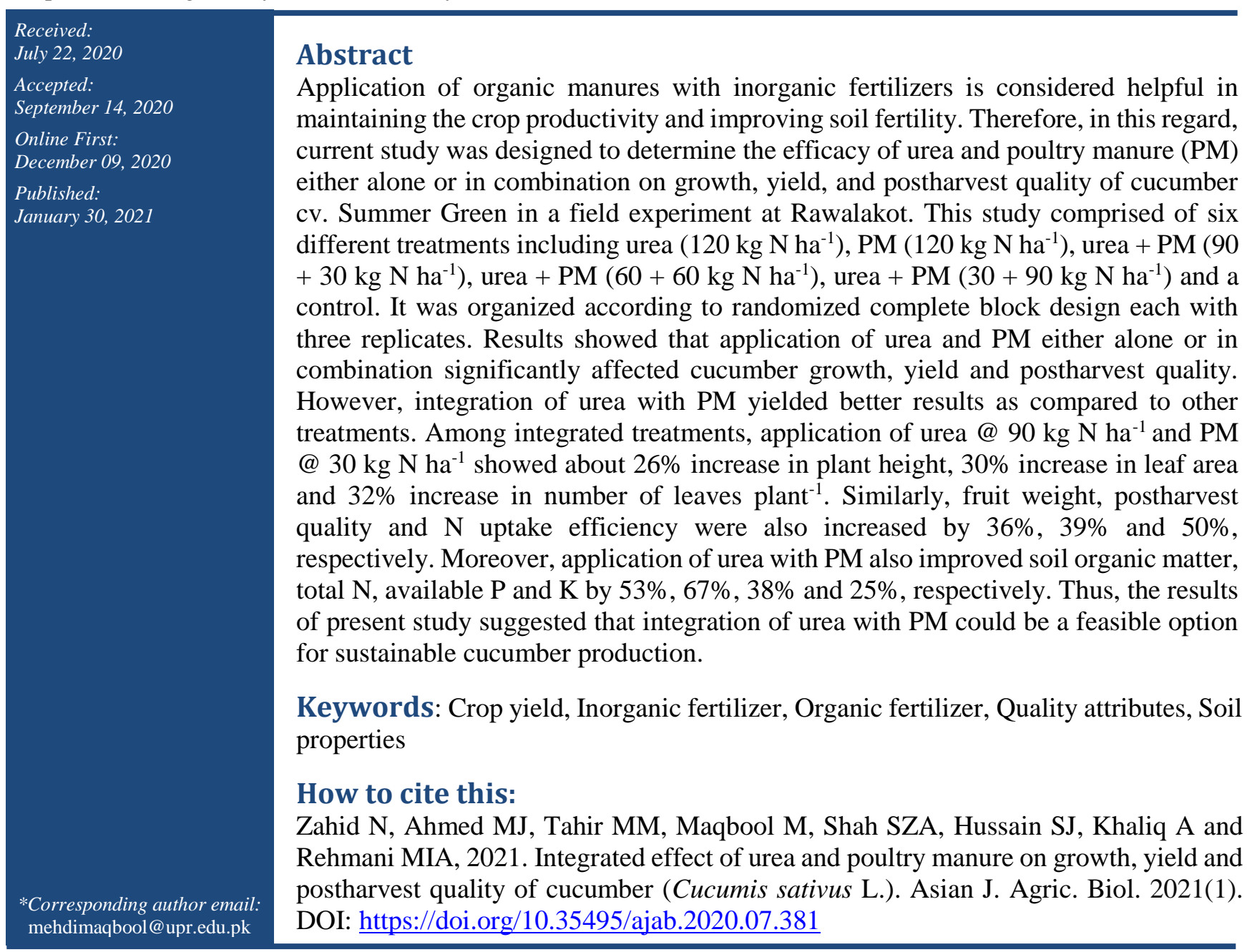

This is an Open Access article distributed under the terms of the Creative Commons Attribution 3.0 License. (https://creativecommons.org/licenses/by/3.0), which permits unrestricted use, distribution, and reproduction in any medium, provided the original work is properly cited. 


\section{Introduction}

Nitrogen $(\mathrm{N})$ is considered as one of the main macronutrients needed by plants (Ali et al., 2017). During the last half of the century significant improvement in crop yields can be attributed to elevated nutrient application (Salim and Raza, 2020). However, inappropriate application of nitrogenous fertilizers resulted in serious issues on environmental health and on human lives (Ahmed et al., 2017; Nieder et al., 2018). Effective nutrient organization is a key to achieve sustainable crop yield and sustainable development goals (Zhang et al., 2015; Ye et al., 2019; Oldroyd and Leyser, 2020), which will not only reduce the cost of production but also will help in minimizing the environmental concerns.

After crop harvest $\mathrm{N}$ applied greater than the crop requirement remains in the soil as residual $\mathrm{N}$ and in crops residues. Both sources of nitrogen not only affect the quality of groundwater due to leaching of nitrates, but also cause air pollution by emission of nitrous oxide (Ekinci et al., 2019). Consequently, meeting $\mathrm{N}$ nutrient requirement of crops without compromising on yield gains and environment will be a vital test for agriculturists (Cameron et al., 2013). Crop management and application of manures significantly influence soil $\mathrm{N}$ dynamics. Manure application potentially lead to soil quality improvement and nutrient increment including $\mathrm{N}$. Moreover, manures can add energy reserve for soil micro-organisms and a vital source of soil nutrients (Ye et al., 2019). Recently, the demand for organic manures has been increased (Teng et al., 2018).

Application of manures in agricultural soils is a feasible approach which can be tried to address the issue of excessive application of fertilizer N. Organic manures have shown significant interaction with nitrogenous fertilizers (Petersen et al., 2012). Poultry manure (PM), is a good option among organic manures which has the potential to provide nutrients for raising crops and improving soil fertility on sustainable basis (Dikinya and Mufwanzala, 2010; Žydelis et al., 2019). When applied by Ashworth et al. (2020), PM not only extended the N supply for a longer period, but also helped in improving ionexchange and water-holding capacity of soil. However, $\mathrm{N}$ from PM is released at slower rates via mineralization which may not meet growing crop $\mathrm{N}$ requirements (Adeyeye et al., 2017). On contrary to that, inorganic fertilizers i.e. urea when applied to soil, yields high level of available $\mathrm{N}$ early in the crop growth that exceeds plant demand and lead to potential $\mathrm{N}$ losses (Adeyeye et al., 2017). Therefore, integrated $\mathrm{N}$ management practice i.e. combined application of PM with urea could be helpful for sustainable crop production and soil quality.

Cucumber (Cucumis sativus L.) is an important member of Cucurbitaceae family which plays a critical role in human diet. Generally, it is a good source of water $(96.3 \%)$, carbohydrates $(2.7 \%)$, proteins $(0.4 \%)$, minerals $(0.4 \%)$ and fats $(0.1 \%)$. It is also a good basis of vitamins (B, C) and dietary fiber in different proportions (Singh et al., 2004; Rajasree et al., 2016; Rolnik and Olas, 2020). As a result of its high nutritional benefits, its production is gradually increasing, both in fields and greenhouses (Zarei et al., 2019). This increased production resulted in depletion of soil organic matter along with compromising on biotic and abiotic constituents of soils.

Small-scale cucumber farmers in AJK state are facing soil fertility linked issues in cucumber production. Moreover, soils of this region are poor in nutrient status (i.e. nitrogen), therefore, these soils can hardly sustain the levels of required production without supplemental fertilization (Malik et al., 2000). Similarly, merely inorganic fertilization is not sufficient to achieve long-term sustainable production. Therefore, application of organic manures with $\mathrm{N}$ fertilizers will not only help in maintaining the crop productivity but it will also help in improving fertility of soil. Considering these facts, this study was designed to assess the integrated effect of urea fertilizer and PM on growth, fruit yield and postharvest quality of cucumber under field conditions.

\section{Material and Methods}

\section{Description of experimental site and design}

This study was performed during 2017-18 at the Agricultural Research Area of University of Poonch Rawalakot $\left(33-36^{\circ} \mathrm{N}\right.$ latitude and $73-75^{\circ} \mathrm{E}$ longitude). This area consists of mainly hills and mountains having sub-humid temperate climate. Rainfall ranges from 500-2000 $\mathrm{mm}$ per annum while mean temperature goes up to $30^{\circ} \mathrm{C}$ (max.) in summer and $0^{\circ} \mathrm{C}$ in winter. Experimental area $\left(125 \mathrm{~m}^{2}\right)$ was manually cleared and debris were removed. Seeds of cucumber cv. Summer Green, obtained from local market, sown in glass house and at two-leaf stage, seedlings were transplanted in the field according to randomized complete block design (RCBD) with 
three replicates. In field 12 seedlings were planted in each bed having $30 \mathrm{~cm}$ plant-to-plant distance and 70 $\mathrm{cm}$ row-to-row distance. This study comprised of six different treatments: urea $\left(120 \mathrm{~kg} \mathrm{~N} \mathrm{ha}^{-1}\right), \mathrm{PM}(120 \mathrm{~kg}$ $\left.\mathrm{N} \mathrm{ha}^{-1}\right)$, urea + PM $\left(90+30 \mathrm{~kg} \mathrm{~N} \mathrm{ha}^{-1}\right)$, urea $+\mathrm{PM}(60$ $\left.+60 \mathrm{~kg} \mathrm{~N} \mathrm{ha}^{-1}\right)$, urea $+\mathrm{PM}\left(30+90 \mathrm{~kg} \mathrm{~N} \mathrm{ha}^{-1}\right)$ including control.

A full dosage of PM was soil incorporated before transplantation of seedlings. While, application of urea was done in three uniform splits, i.e. first dose was applied at transplanting stage, second after transplanting (one month later) and third at fruiting time. Further, $60 \mathrm{~kg} \mathrm{ha}^{-1}$ potash and $80 \mathrm{~kg} \mathrm{ha}^{-1}$ phosphorus (P) were also applied as a basal dose (Okoli and Nweke, 2015).

\section{Physicochemical attributes of soil and PM}

Physiochemical analysis of randomly selected soil samples (Pre and post experiment, 0-30 cm depth) from experimental site and PM used in this experiment was done at Horticulture Lab, University of Poonch Rawalakot. Before chemical analysis PM was air dried, mashed and sieved ( $2 \mathrm{~mm}$ sieve). Before application, soil and PM samples were collected to analyze soil $\mathrm{pH}$, total $\mathrm{N}$, available $\mathrm{P}$, total organic carbon, available potassium $(\mathrm{K})$ and texture (Table 1$)$. Total $\mathrm{N}$ was calculated by Kjeldhal method as given by Sáez-Plaza et al. (2013), available P by Follain et al. (2009) method, available $\mathrm{K}$ by Affinnih et al. (2014) method, total organic carbon by wet-oxidation procedure given by Mingorance et al. (2007) and texture of soil was measured using hydrometeric method given by Beretta et al. (2014).

Effect of urea and PM (alone and combined) on growth parameters of cucumber was studied on the basis of survival percentage, no. of leaves plant ${ }^{-1}(20$ days after transplantation), average no. of branches plant $^{-1}$, plant height, leaf area, no. of leaves plant ${ }^{-1}$. Efficacy of urea and PM (alone and combined) on parameters related to yield of cucumber were studied by counting no. of days to flower, no. of female flowers, avg. no. of fruit plant $^{-1}$, length of fruit, diameter of fruit, weight of fruit and no. of seeds fruit ${ }^{-}$ 1. Effect of urea and PM (alone and combined) on postharvest quality of cucumber were recorded by measuring relative water content, total soluble solids using refractometer and ascorbic acid using standard methods (AOAC, 1990; Method No. 967.22).

Efficacy of urea and PM (alone and combined) on $\mathrm{N}$ concentration and $\mathrm{N}$-uptake efficiency was also measured. Collected samples were initially air dried, sliced into tiny pieces, dried again $\left(65^{\circ} \mathrm{C}\right)$ in an oven to attain a constant sample weight. Oven dried plant material grind in a Micro Wiley Mill having 1-mm sieve. Kjeldahl method was used to measure total $\mathrm{N}$ concentration. $\mathrm{N}$-uptake efficiency by cucumber was taken based on plant $\mathrm{N}$ concentration and dry matter yield. $\mathrm{N}$ content were examined at vegetative, flowering and harvesting stages. Fruit $\mathrm{N}(\%)$ was also determined at three stages of fruit development i.e. young fruit, pre-mature fruit and mature fruit. $\mathrm{N}$ uptake efficiency was also measured by using the formula given below (Jiang et al., 2016).

$\mathrm{N}$-uptake efficiency $=\frac{\mathrm{N} \text {-uptake by fertilized treatment-N uptake by control }}{\text { Amount of total } \mathrm{N} \text { fertilizer applied }} \times 100$

After completion of experiment, samples of soil from all the treatments were taken in triplicate and analyzed for soil organic matter, total $\mathrm{N}$, available $\mathrm{P}$ and available $\mathrm{K}$ to estimate the changes in their content.

Table-1: Physicochemical properties of soil and PM before planting cucumber (Cucumis sativus $\mathbf{L}$.) $(\mathrm{n}=3$ )

\begin{tabular}{|l|c|c|}
\hline \multicolumn{1}{|c|}{ Parameters } & Soil & PM \\
\hline $\mathrm{pH}$ & 7.40 & 6.78 \\
\hline Total N (\%) & 0.016 & 2.91 \\
\hline Available P $\left(\mathrm{mg} \mathrm{kg}^{-1}\right)$ & 5.66 & 1.90 \\
\hline Available K $\left(\mathrm{mg} \mathrm{kg}^{-1}\right)$ & 96.67 & 1.05 \\
\hline Soil organic matter (\%) & 0.33 & - \\
\hline Sand $\left(\mathrm{g} \mathrm{kg}^{-1}\right)$ & 450 & - \\
\hline Silt $\left(\mathrm{g} \mathrm{kg}^{-1}\right)$ & 260 & - \\
\hline Clay $\left(\mathrm{g} \mathrm{kg}^{-1}\right)$ & 280 & - \\
\hline
\end{tabular}

\section{Statistical analysis}

Statistical design used for this study was RCBD with each treatment replicated thrice and every replication consisted of twelve plants. The experiment was repeated twice and results were pooled for analysis as the important outcomes of separate analysis showed almost parallel results across the experiment. Data collected during this study was subjected to AVONA. Statistical software Statistix 8.1 (Analytical software, Tallahassee, FL, USA) was used for analysis, while the treatment means comparison was done by Tukey's test at $P \leq 0.05$.

\section{Results}

Effect of urea and PM (alone and combined) on growth parameters of cucumber

Results regarding growth parameters of cucumber 
were significantly $(P \leq 0.05)$ influenced by urea, PM and their combination when compared with control (Table 2). Application of urea @ $120 \mathrm{~kg} \mathrm{~N} \mathrm{ha}{ }^{-1}$ significantly improved growth when compared with PM@120 kg N ha-1. However, application of urea with PM further improved the growth of cucumber compared to its sole application. Among the integrated treatments where urea was combined with PM, maximum seedling survival percentage $(85.6 \%)$, maximum no. of leaves plant ${ }^{-1}$ after 20 days of transplantation (11.9), avg. no. of branches plant ${ }^{-1}$ (13.4), plant height $(560.2 \mathrm{~cm})$, leaf area $\left(215.3 \mathrm{~cm}^{2}\right)$ and no. of leaves plant ${ }^{-1}$ (64.5) were recorded in the treatment where urea @ $90 \mathrm{~kg} \mathrm{~N} \mathrm{ha}{ }^{-1}$ was combined with PM@ $30 \mathrm{~kg} \mathrm{~N} \mathrm{ha}{ }^{-1}$. Conversely, among the integrated treatments lowest seedling survival percentage $(29.0 \%)$, minimum no. of leaves plant $^{-1}$ after 20 days of transplantation (6.4), avg. no. of branches plant ${ }^{-1}(4.8)$, plant height $(153.2 \mathrm{~cm})$, leaf area $\left(111.2 \mathrm{~cm}^{2}\right)$ and no. of leaves plant ${ }^{-1}(24.4)$ were recorded in control treatment. Other combined treatments of urea $+\mathrm{PM}\left(60+60 \mathrm{~kg} \mathrm{~N} \mathrm{ha}^{-1}\right)$ and urea $+\mathrm{PM}\left(30+90 \mathrm{~kg} \mathrm{~N} \mathrm{ha}^{-1}\right)$ also showed comparatively better results when compared with control in terms of all the parameters recorded, however, the efficiency of those treatments was not that considerable as urea + PM $\left(90+30 \mathrm{~kg} \mathrm{~N} \mathrm{ha}^{-1}\right)$.
Effect of urea and PM (alone and combined) on yield parameters of cucumber

Yield attributes of cucumber were significantly $(P \leq$ 0.05 ) affected by the application of urea, PM either alone or in combination when compared with control (Table 3). Application of urea @ $120 \mathrm{~kg} \mathrm{~N} \mathrm{ha}^{-1}$ significantly improved growth when compared with PM@120 kg N ha ${ }^{-1}$. However, application of urea with PM further improved the growth of cucumber compared to its sole application. Among integrated treatments, least no. of days to flower (29.9), maximum no. of female flowers (23.4), avg. no. of fruit plant ${ }^{-1}(15.50)$, length of fruit $(25.64 \mathrm{~cm})$, diameter of fruit $(7.48 \mathrm{~cm})$, weight of fruit $(894.0 \mathrm{~g})$ and no. of seeds fruit ${ }^{-1}$ (459.9) were recorded in the treatment where urea @ $90 \mathrm{~kg} \mathrm{~N} \mathrm{ha}{ }^{-1}$ was combined with PM @ $30 \mathrm{~kg} \mathrm{~N} \mathrm{ha}^{-1}$. On the other hand, highest no. of days to flower (59.6), minimum no. of female flowers (6.8), avg. no. of fruit plant ${ }^{-1}(4.4)$, length of fruit $(13.0 \mathrm{~cm})$, diameter of fruit $(2.6 \mathrm{~cm})$, weight of fruit $(247.5 \mathrm{~g})$ and no. of seeds fruit ${ }^{-1}(142.8)$ were recorded in control treatment. Other combined treatments of urea $+\mathrm{PM}\left(60+60 \mathrm{~kg} \mathrm{~N} \mathrm{ha}^{-1}\right)$ and urea $+\mathrm{PM}\left(30+90 \mathrm{~kg} \mathrm{~N} \mathrm{ha}^{-1}\right)$ also showed comparatively better results when compared with control in terms of all the parameters recorded, however, the efficiency of those treatments was not that considerable as urea + $\mathrm{PM}\left(90+30 \mathrm{~kg} \mathrm{~N} \mathrm{ha}^{-1}\right)$.

Table-2: Efficacy of urea and PM (alone and combined) on growth parameters of cucumber (Cucumis sativus L.)

\begin{tabular}{|c|c|c|c|c|c|c|}
\hline Treatments & $\begin{array}{c}\text { Seedling } \\
\text { Survival } \\
\text { percentage }\end{array}$ & $\begin{array}{c}\text { No. of leaves } \\
\text { plant }^{-1} \\
20 \text { DAT }\end{array}$ & $\begin{array}{c}\text { Avg. no. of } \\
\text { branches } \\
\text { plant }^{-1}\end{array}$ & $\begin{array}{c}\text { Plant } \\
\text { height } \\
(\mathbf{c m})\end{array}$ & $\begin{array}{l}\text { Leaf } \\
\text { area } \\
\left(\mathrm{cm}^{2}\right)\end{array}$ & $\begin{array}{l}\text { No. of } \\
\text { leaves } \\
\text { plant }^{-1}\end{array}$ \\
\hline Control & $29.0 \mathrm{c}$ & $6.4 \mathrm{~d}$ & $4.8 \mathrm{c}$ & $153.2 \mathrm{c}$ & $111.2 \mathrm{c}$ & $24.4 \mathrm{e}$ \\
\hline Urea $\left(120 \mathrm{~kg} \mathrm{~N} \mathrm{ha}^{-1}\right)$ & $60.5 \mathrm{~b}$ & $9.2 \mathrm{bc}$ & $9.5 \mathrm{~b}$ & $487.4 \mathrm{a}$ & $160.7 \mathrm{abc}$ & $46.8 \mathrm{bc}$ \\
\hline PM (120 kg N ha $\left.{ }^{-1}\right)$ & $60.0 \mathrm{~b}$ & $8.5 \mathrm{bcd}$ & $8.9 \mathrm{~b}$ & $340.5 \mathrm{~b}$ & $139.6 \mathrm{bc}$ & $39.3 \mathrm{~cd}$ \\
\hline Urea $\left(90 \mathrm{~kg} \mathrm{~N} \mathrm{ha}^{-1}\right)+\mathrm{PM}\left(30 \mathrm{~kg} \mathrm{~N} \mathrm{ha}^{-1}\right)$ & $85.5 \mathrm{a}$ & $11.9 \mathrm{a}$ & $13.4 \mathrm{a}$ & $560.2 \mathrm{a}$ & $215.3 \mathrm{a}$ & $64.5 \mathrm{a}$ \\
\hline Urea $\left(60 \mathrm{~kg} \mathrm{~N} \mathrm{ha}^{-1}\right)+\mathrm{PM}\left(60 \mathrm{~kg} \mathrm{~N} \mathrm{ha}^{-1}\right)$ & $62.2 \mathrm{~b}$ & $10.7 \mathrm{ab}$ & $11.3 \mathrm{ab}$ & $335.9 \mathrm{~b}$ & $185.7 \mathrm{ab}$ & $50.2 \mathrm{~b}$ \\
\hline Urea $\left(30 \mathrm{~kg} \mathrm{~N} \mathrm{ha}^{-1}\right)+\mathrm{PM}\left(90 \mathrm{~kg} \mathrm{~N} \mathrm{ha}^{-1}\right)$ & $48.8 \mathrm{bc}$ & $7.6 \mathrm{~cd}$ & $9.3 \mathrm{~b}$ & $285.1 \mathrm{~b}$ & $126.2 \mathrm{bc}$ & $35.9 \mathrm{~d}$ \\
\hline LSD 0.05 & 19.96 & 2.51 & 3.74 & 76.24 & 60.51 & 9.78 \\
\hline
\end{tabular}

PM: Poultry manure; N: Nitrogen; DAT: days after transplanting; LSD: Least significant difference According to ANOVA and Tukey's test at $P \leq 0.05$, means showing different letters are significantly different. 
Noosheen Zahid et al.

Table-3: Efficacy of urea and PM (alone and combined) on yield parameters of cucumber (Cucumis sativus L.)

\begin{tabular}{|l|c|c|c|c|c|c|c|}
\hline \multicolumn{1}{|c|}{ Treatments } & $\begin{array}{c}\text { No. of days to } \\
\text { flowering }\end{array}$ & $\begin{array}{c}\text { No. of female } \\
\text { flowers }\end{array}$ & $\begin{array}{c}\text { Avg. no. of } \\
\text { fruit plant }\end{array}$ & $\begin{array}{c}\text { Length of } \\
\text { fruit (cm) }\end{array}$ & $\begin{array}{c}\text { Diameter of } \\
\text { fruit (cm) }\end{array}$ & $\begin{array}{c}\text { Weight of } \\
\text { fruit (g) }\end{array}$ & $\begin{array}{c}\text { No. of seeds } \\
\text { fruit }\end{array}$ \\
\hline Control & $59.6 \mathrm{a}$ & $6.8 \mathrm{e}$ & $4.4 \mathrm{~d}$ & $13.0 \mathrm{~d}$ & $2.6 \mathrm{~d}$ & $247.5 \mathrm{~d}$ & $142.8 \mathrm{~d}$ \\
\hline Urea $\left(120 \mathrm{~kg} \mathrm{~N} \mathrm{ha}^{-1}\right)$ & $41.0 \mathrm{c}$ & $14.1 \mathrm{c}$ & $11.1 \mathrm{~b}$ & $21.1 \mathrm{~b}$ & $5.5 \mathrm{~b}$ & $583.0 \mathrm{bc}$ & $342.2 \mathrm{~b}$ \\
\hline PM $\left(120 \mathrm{~kg} \mathrm{~N} \mathrm{ha}^{-1}\right)$ & $49.4 \mathrm{~b}$ & $13.2 \mathrm{c}$ & $9.2 \mathrm{c}$ & $16.5 \mathrm{c}$ & $4.4 \mathrm{bc}$ & $556.5 \mathrm{c}$ & $252.7 \mathrm{c}$ \\
\hline Urea $\left(90 \mathrm{~kg} \mathrm{~N} \mathrm{ha}^{-1}\right)+$ PM $\left(30 \mathrm{~kg} \mathrm{~N} \mathrm{ha}^{-1}\right)$ & $29.9 \mathrm{e}$ & $23.4 \mathrm{a}$ & $15.5 \mathrm{a}$ & $25.6 \mathrm{a}$ & $7.4 \mathrm{a}$ & $894.0 \mathrm{a}$ & $459.9 \mathrm{a}$ \\
\hline Urea $\left(60 \mathrm{~kg} \mathrm{~N} \mathrm{ha}^{-1}\right)+$ PM $\left(60 \mathrm{~kg} \mathrm{~N} \mathrm{ha}^{-1}\right)$ & $37.4 \mathrm{~d}$ & $19.1 \mathrm{~b}$ & $12.3 \mathrm{~b}$ & $22.4 \mathrm{~b}$ & $5.4 \mathrm{~b}$ & $802.4 \mathrm{ab}$ & $350.8 \mathrm{~b}$ \\
\hline Urea $\left(30 \mathrm{~kg} \mathrm{~N} \mathrm{ha}^{-1}\right)+$ PM $\left(90 \mathrm{~kg} \mathrm{~N} \mathrm{ha}^{-1}\right)$ & $50.5 \mathrm{~b}$ & $10.9 \mathrm{~d}$ & $8.4 \mathrm{c}$ & $16.1 \mathrm{c}$ & $4.1 \mathrm{c}$ & $336.2 \mathrm{~cd}$ & $238.8 \mathrm{c}$ \\
\hline LSD 0.05 & 3.41 & 1.92 & 1.68 & 2.60 & 1.27 & 223.28 & 41.82 \\
\hline
\end{tabular}

PM: Poultry manure; N: Nitrogen; LSD: Least significant difference

According to ANOVA and Tukey's test at $P \leq 0.05$, means showing different letters are significantly different.

Effect of urea and PM (alone and combined) on postharvest quality of cucumber

Postharvest quality of cucumber was significantly $(P$ $\leq 0.05$ ) influenced by the application of urea, PM either alone or in combination when compared with control (Table 4). Application of urea @ $120 \mathrm{~kg} \mathrm{~N} \mathrm{ha}^{-}$ ${ }^{1}$ significantly improved growth when compared with PM@120 kg N ha ${ }^{-1}$. However, application of urea with PM further improved the growth of cucumber compared to its sole application. Among integrated treatments, highest amount of relative water content (88.1), total soluble solids (3.1\%) and ascorbic acid $(0.6 \%)$ were recorded in the treatment where urea @ $90 \mathrm{~kg} \mathrm{~N} \mathrm{ha}{ }^{-1}$ was combined with PM @ 30 kg N ha ${ }^{-1}$. On the other hand, the lowest amount of relative water content (47.5), total soluble solids (1.0\%) and ascorbic acid $(0.1 \%)$ were recorded in control treatment.

Table-4: Efficacy of urea and PM (alone and combined) on postharvest quality of cucumber (Cucumis sativus L.)

\begin{tabular}{|l|c|c|c|}
\hline \multicolumn{1}{|c|}{ Treatments } & $\begin{array}{c}\text { Relative } \\
\text { water } \\
\text { content }\end{array}$ & $\begin{array}{c}\text { Total } \\
\text { soluble } \\
\text { solids (\%) }\end{array}$ & $\begin{array}{c}\text { Ascorbic } \\
\text { acid (\%) }\end{array}$ \\
\hline Control & $47.5 \mathrm{c}$ & $1.0 \mathrm{c}$ & $0.1 \mathrm{~d}$ \\
\hline Urea $\left(120 \mathrm{~kg} \mathrm{~N} \mathrm{ha}^{-1}\right)$ & $65.7 \mathrm{bc}$ & $2.3 \mathrm{ab}$ & $0.5 \mathrm{~b}$ \\
\hline PM $\left(120 \mathrm{~kg} \mathrm{~N} \mathrm{ha}^{-1}\right)$ & $60.5 \mathrm{bc}$ & $1.4 \mathrm{bc}$ & $0.2 \mathrm{c}$ \\
\hline $\begin{array}{l}\text { Urea }\left(90 \mathrm{~kg} \mathrm{~N} \mathrm{ha}^{-1}\right)+ \\
\text { PM }\left(30 \mathrm{~kg} \mathrm{~N} \mathrm{ha}^{-1}\right)\end{array}$ & $88.1 \mathrm{a}$ & $3.1 \mathrm{a}$ & $0.6 \mathrm{a}$ \\
\hline $\begin{array}{l}\text { Urea }\left(60 \mathrm{~kg} \mathrm{~N} \mathrm{ha}^{-1}\right)+ \\
\text { PM }\left(60 \mathrm{~kg} \mathrm{~N} \mathrm{ha}^{-1}\right)\end{array}$ & $71.3 \mathrm{ab}$ & $2.6 \mathrm{a}$ & $0.5 \mathrm{~b}$ \\
\hline $\begin{array}{l}\text { Urea }\left(30 \mathrm{~kg} \mathrm{~N} \mathrm{ha}^{-1}\right)+ \\
\text { PM }\left(90 \mathrm{~kg} \mathrm{~N} \mathrm{ha}^{-1}\right)\end{array}$ & $58.7 \mathrm{bc}$ & $1.4 \mathrm{bc}$ & $0.2 \mathrm{c}$ \\
\hline LSD 0.05 & 18.12 & 1.0 & 0.07 \\
\hline PM:
\end{tabular}

PM: Poultry manure; N: Nitrogen; LSD: Least significant difference
According to ANOVA and Tukey's test at $P \leq 0.05$, means showing different letters are significantly different.

Effect of urea and PM (alone and combined) on plant $\mathrm{N}$ concentration and $\mathrm{N}$-uptake efficiency by cucumber

$\mathrm{N}$ content of cucumber root, shoot and leaf were significantly $(P \leq 0.05)$ influenced by the application of urea, PM either alone or in combination when compared with control (Fig. 1). Application of urea @ $120 \mathrm{~kg} \mathrm{~N} \mathrm{ha}^{-1}$ significantly enhanced $\mathrm{N}$ content when compared with PM @ $120 \mathrm{~kg} \mathrm{~N} \mathrm{ha}{ }^{-1}$. However, application of urea with PM further enhanced cucumber root, shoot and leaf $\mathrm{N}$ content at all stages i.e. vegetative, flowering and harvesting. Among integrated treatments, highest $\mathrm{N}$ content of root [Fig. 1 (a, b, c)], shoot [Fig. 1 (d, e, f)] and leaf [Fig. 1 (g, h, i)] were recorded in the treatment where urea @ 90 $\mathrm{kg} \mathrm{N} \mathrm{ha}{ }^{-1}$ was combined with PM @ $30 \mathrm{~kg} \mathrm{~N} \mathrm{ha}^{-1}$.

Table-5: Efficacy of urea and PM (alone and combined) on N-uptake efficiency (\%) by cucumber (Cucumis sativus L.)

\begin{tabular}{|l|c|}
\hline \multicolumn{1}{|c|}{ Treatments } & $\begin{array}{c}\text { N-uptake } \\
\text { efficiency }(\%)\end{array}$ \\
\hline Urea $\left(120 \mathrm{~kg} \mathrm{~N} \mathrm{ha}^{-1}\right)$ & $23.6 \mathrm{~d}$ \\
\hline PM $\left(120 \mathrm{~kg} \mathrm{~N} \mathrm{ha}^{-1}\right)$ & $39.0 \mathrm{bc}$ \\
\hline Urea $\left(90 \mathrm{~kg} \mathrm{~N} \mathrm{ha}^{-1}\right)+\mathrm{PM}\left(30 \mathrm{~kg} \mathrm{~N} \mathrm{ha}^{-1}\right)$ & $62.0 \mathrm{a}$ \\
\hline Urea $\left(60 \mathrm{~kg} \mathrm{~N} \mathrm{ha}^{-1}\right)+\mathrm{PM}\left(60 \mathrm{~kg} \mathrm{~N} \mathrm{ha}^{-1}\right)$ & $48.7 \mathrm{~b}$ \\
\hline Urea $\left(30 \mathrm{~kg} \mathrm{~N} \mathrm{ha}^{-1}\right)+\mathrm{PM}\left(90 \mathrm{~kg} \mathrm{~N} \mathrm{ha}^{-1}\right)$ & $27.6 \mathrm{~cd}$ \\
\hline LSD 0.05 & 12.26 \\
\hline
\end{tabular}

PM: Poultry manure; N: Nitrogen; LSD: Least significant difference 
According to ANOVA and Tukey's test at $P \leq 0.05$, means showing different letters are significantly different.

Fruit $\mathrm{N}$ content showed similar trend and the highest $\mathrm{N}$ content in cucumber fruits at young, pre-mature and mature fruit stages were found in the treatment where urea@90 kg N ha-1 was combined with PM @ $30 \mathrm{~kg}$ $\mathrm{N}^{-1}$ [Fig. 2 (a, b, c)]. N-uptake efficiency (\%) was also enhanced by the combined application of urea and PM and maximum $\mathrm{N}$-uptake efficiency $(62.0 \%)$ was observed in the treatment where urea @ $90 \mathrm{~kg} \mathrm{~N}$ ha $^{-1}$ was combined with PM @ $30 \mathrm{~kg} \mathrm{~N} \mathrm{ha}^{-1}$ (Table 5). On the other hand, lowest $\mathrm{N}$-uptake efficiency $(23.6 \%)$ was recorded in the treatment where urea @ $120 \mathrm{~kg} \mathrm{~N} \mathrm{ha}^{-1}$ was applied alone.

\section{Effect of urea and PM (alone and combined) on soil properties}

Soil organic matter, total $\mathrm{N}$, available $\mathrm{P}$ and available $\mathrm{K}$ were estimated after the completion of experiment. Results regarding these parameters revealed that a significant $(P \leq 0.05)$ influence of urea combined with PM was recorded on soil properties [(Fig. 3 (a, b, c, d)]. Among integrated treatments, the highest values of soil organic matter $(0.9 \%)$, total $\mathrm{N}(0.04 \%)$, available $\mathrm{P}\left(9.2 \mathrm{mg} \mathrm{kg}^{-1}\right)$ and available $\mathrm{K}(130.0 \mathrm{mg}$ $\mathrm{kg}^{-1}$ ) were recorded in the treatment where urea @ 90 $\mathrm{kg} \mathrm{N} \mathrm{ha}{ }^{-1}$ was combined with PM @ $30 \mathrm{~kg} \mathrm{~N} \mathrm{ha}^{-1}$. On the other hand, the lowest soil organic matter $(0.3 \%)$ and total $\mathrm{N}(0.016 \%)$ were found in control treatment. Available $\mathrm{P}\left(5.3 \mathrm{mg} \mathrm{kg}^{-1}\right)$ and available $\mathrm{K}\left(86.6 \mathrm{mg} \mathrm{kg}^{-}\right.$ $\left.{ }^{1}\right)$ content were the lowest in treatment where urea was applied @ $120 \mathrm{~kg} \mathrm{~N} \mathrm{ha}^{-1}$ alone which was followed by the control treatment $\left(5.66 \mathrm{mg} \mathrm{kg}^{-1}\right)$ and $\left(96.6 \mathrm{mg} \mathrm{kg}^{-}\right.$ $\left.{ }^{1}\right)$, respectively.

\section{Discussion}

Result of the present study revealed that growth, yield and postharvest quality of cucumber was improved, and the highest values were recorded in treatments where urea was combined with PM rather than sole application of either urea or PM. Improved growth, yield and postharvest quality of cucumber in those treatments could be attributed to the synchronization of nutrient release from urea and PM (Ghanbarian et al., 2008). Soil is storehouse of nutrients and plays vital role for production of fruits and vegetables. However, its fertility is degrading day by day due to intensive crop production, heavy fertilization, and mono cropping (Bennet et al., 2012). High doses of chemical fertilizers have shown negative impact on soil fertility, while reduced applications have lowered the crop yields (Pradeepkumar et al., 2017). Addition of manures i.e. PM in soil sustain crop yields and improves soil properties and fertility (Dikinya and Mufwanzala, 2010; Enujeke, 2013). Further, incorporation of organic manure with $\mathrm{N}$ increases the availability of $\mathrm{P}$ in soil and results in increased uptake of nutrients (Adeyeye et al., 2107). This increased uptake of nutrients resulted in increased number of leaves per branch and number of branches per plant (Adeyeye et al., 2107).

In current study it was observed that the treatment in which urea @ $90 \mathrm{~kg} \mathrm{ha}^{-1}$ was combined with PM @ 30 $\mathrm{kg} \mathrm{ha}{ }^{-1}$, seedling survival percentage, number of branches, plant height and number of leaves plant $^{-1}$ were increased to maximum (Table 2). Application of $\mathrm{PM}$ with fertilizer $\mathrm{N}$ is reported to increase leaf surface area and number of leaves plant ${ }^{-1}$ which ultimately lead to higher photosynthetic rate and consequently higher yields (Quansah, 2010). Similarly, in this study maximum fruit weight, fruit length and diameter were recorded in those treatments where urea was combined with PM (Table 3). Reduction in number of days to flowering and increased number of female flowers in combined treatments of urea and PM could be attributed to the increased uptake of $\mathrm{N}$ followed by increased gibberallic acid production which increased plant vigor (Anjanappa et al., 2012). So, it could be attributed that gibberellic acid was responsible for increased flower production and more female flowers in cucumber. Our findings are at par with the findings of Ewulo et al. (2008), who reported that PM increased nutrient content and nutrient uptake leading to improved crop yields. Increased growth and yield of cucumber in treatments where urea was combined with PM could be related to the phenomenon that microbes present in PM sustained $\mathrm{N}$ mineralization, thereby providing $\mathrm{N}$ at a constant rate according to the requirements of the crop (Onwu et al., 2008; Žydelis et al., 2019). Generally, it is considered that the organic matter obtained from animal origin is helpful in increasing soil organic matter which is consequently responsible for increased vegetative growth and crop yield (Eifediyi et al., 2017).

Increased amount of $\mathrm{N}$ and available $\mathrm{P}$ in case of combined treatments ensured an increase of $\mathrm{N}$ in roots, shoots, leaves and fruit of cucumber (Fig 1 and 2). This increased concentration of $\mathrm{N}$ in roots resulted in increased root and shoot diameter. In connection to 
that, a positive correlation was reported with higher $\mathrm{N}$ content in leaves and fruit yield (Baiyeri and Tenkouano, 2008). Additionally, it has also been observed that PM helped to change the soil properties and also improved the cation exchange capacity which was helpful in absorption of macronutrients (Onwu et al., 2014). Similarly, an increased amount of N content can lead to increased concentration of vitamin B1 and several antioxidants in fruits (Mozafar, 2008). Cucumbers also contain several antioxidants, including vitamin $\mathrm{C}$, beta-carotene and manganese, as well as flavonoids, triterpenes and lignans that have anti-inflammatory properties (Chu et al., 2002). So, in this study, combined treatment of urea + PM $(90+30$ $\mathrm{kg} \mathrm{ha}^{-1}$ ) showed the highest amount of $\mathrm{N}$ in cucumber fruits which can improve vitamins and antioxidants found in cucumber essential for human health.

It was observed that addition of PM with urea resulted in increased amount of soil organic matter, total $\mathrm{N}$, available $\mathrm{P}$ and $\mathrm{K}$ (Fig 3). The reason behind this could be the amount of added PM which was also evident from this study since the highest soil organic matter was found in those treatments where maximum PM was applied (Dikinya and Mufwanzala, 2010). Increased N content in soil treated with PM could be related to soil organic matter i.e. the higher soil organic matter the higher total N. Similarly, enhanced available P in soil after PM application was possibly due to the amount of P present in PM (Eghball and Power, 1999). On the other hand, higher $\mathrm{K}$ content in PM treatment was possibly due to 1) amount of $\mathrm{K}$ present in PM and 2) release of colloids from PM with tremendous cation exchange properties that attracted and released $\mathrm{K}$ from non-exchangeable pool (Panwar et al., 2010). It was also reported that application of organic manures reduced $\mathrm{K}$ fixation which also enhanced $\mathrm{K}$ availability and uptake (Ramesh et al., 2009). Results of this study were in line with the findings of Bulluck et al. (2002) who reported that available $\mathrm{K}$ content in soil significantly increased in treatments where manures were applied. Moreover, it was also observed that application of PM with urea significantly enhanced $\mathrm{N}$ uptake efficiency (Table 5). Similar results were reported by Nweke and Nsoanya (2015) when organic manure was combined with chemical fertilizer. They explained that this increased nutrient uptake efficiency was due to the availability and release of nutrients by PM throughout the growing period.

\section{Conclusion}

It can be concluded from this study that integration of PM with urea is a feasible option for sustainable production of cucumber and improving soil fertility. Application of urea @ $90 \mathrm{~kg} \mathrm{~N} \mathrm{ha}^{-1}$ combined with PM (a) $30 \mathrm{~kg} \mathrm{~N} \mathrm{ha}^{-1}$ proved to be the most promising combination. Improved growth, yield and postharvest quality of cucumber were mainly due to the increased nutrient availability and uptake. Therefore, integration of organic manure with inorganic fertilizers could be recommended for environment friendly sustainable agriculture.

\section{Acknowledgement}

Authors are thankful to the Farm Manager, University of Poonch Rawalakot for providing land and other resources to complete this study at University Research Area.

Disclaimer: None.

Conflict of Interest: None.

Source of Funding: This research work was financially supported by University of Poonch Rawalakot, AJ\&K, Pakistan.

\section{References}

Adeyeye AS, Togun AO, Olaniyan AB and Akanbi WB, 2017. Effect of fertilizer and rhizobium inoculation on growth and yield of soyabean variety (Glycine max L. Merrill). Adv. Crop Sci. Technol. 5: 255.

Affinnih KO, Salawu IS and Isah AS, 2014. Methods of available potassium assessment in selected soils of Kwara state, Nigeria. Agrosearch. 14: 76-87.

Ahmed M, Rauf M, Mukhtar Z and Saeed NA, 2017. Excessive use of nitrogenous fertilizers: an unawareness causing serious threats to environment and human health. Environ. Sci. Pollut. Res. 24: 26983-26987.

Ali I, Zamir SI, Hussain M, Shan MD and Ajmal M, 2017. Agro-economic studies of different oat (Avena sativa L.) cultivars under varying nitrogen levels. J. Environ. Agric. Sci. 13: 31-39.

Anjanappa M, Venkatesh J and Kumara BS, 2012. Influence of organic, inorganic and bio fertilizers on flowering, yield and yield attributes of cucumber (cv. Hassan Local) in open field condition. Karnataka J. Agric. Sci. 25: 493-497. 
AOAC, 1990. Official method of analysis. The Association of Official Analytical Chemistry Washington $14^{\text {th }}$ Edit. Arlington. 1: 88-91.

Ashworth AJ, Chastain JP and Moore Jr. PA, 2020. Nutrient Characteristics of Poultry Manure and Litter. Animal Manure. pp. 63-87.

Baiyeri K and Tenkouano A, 2008. Manure placement effects on root and shoot growth and nutrient uptake of 'PITA 14' plantain hybrid (Musa sp. AAAB). Afr. J. Agric. Res. 3: 013-021.

Beretta AN, Silbermann AN, Paladino L, Torres D, Bassahun D, Musseli R and Gracía-Lamohte A, 2014. Soil texture analyses using hydrometer: modification of Bouyoucos method. Ciencia e Investigation Agraria. 42: 263-271.

Bulluck LR, Brosius M, Evanylo GK and Ristaino JB, 2002. Organic and synthetic fertility amendment influence soil microbial physical and chemical properties on organic and conventional farms. Appl. Soil Ecol. 19: 147-160.

Cameron KC, Di HJ and Moir JL, 2013. Nitrogen losses from the soil/plant system: a review. Ann. Appl. Biol. 162(2): 145-173.

Chu YF, Sun J, Wu X and Liu RH, 2002. Antioxidant and antiproliferative activities of common vegetables. J. Agric. Food Chem. 50: 6910-6916.

Dikinya $\mathrm{O}$ and Mufwanzala N, 2010. Chicken manureenhanced soil fertility and productivity: Effects of application rates. J. Soil Sci. Environ. Manage. 1: 46-54.

Eghball B and Power JF, 1999. Phosphorus- and nitrogen-based manure and compost applications: corn production and soil phosphorus. Soil Sci. Soc. Am. J. 63: 895-901.

Eifediyi EK, Remison SU, Ahamefule HE, Azeez KO and Fesobi PO, 2017. Performance of watermelon (Citrullus lanatus L.) in response to organic and NPK fertilizers. Acta Universitatis Sapienttiae, Agric. Environ. 9: 5-17.

Ekinci M, Atamanalp M, Turan M, Alak G, Kul R, Kitir $\mathrm{N}$ and Yildirim E, 2019. Integrated use of nitrogen fertilizer and fish manure: effects on the growth and chemical composition of spinach. Commun. Soil Sci. Plant Anal. 50(13): 1580-1590.

Enujeke EC, 2013. Growth and yield responses of cucumber to five different rates of poultry manure in Asaba area of Delta state, Nigeria. Int. Res. J. Agric. Sci. Soil Sci. 3: 369-375.

Ewulo BS, Ojeniyi SO and Akanni DA, 2008. Effect of poultry manure on selected soil physical and chemical properties, growth, yield and nutrient status of tomato. Afr. J. Agric. Res. 3: 612-616.

Follain S, Schartz C, Denoroy P, Villette C, Saby NPA, Arrouays D, Lemercier B and Walter C, 2009. A method for assessing available phosphorus content in arable top soils over large spatial scales. Agron. Suitable Develop. 29: 371-379.

Ghanbarian D, Youneji S, Fallah S and Farhadi A, 2008. Effect of broiler litter on physical properties, growth and yield of two cultivars of cantaloupe (Cucumis melo L.). Int. J. Agric. Biol. 10: 697-700.

Jiang P, Xie X, Huang M, Zhou X, Zhang R, Chen J, Wu D, Xia B, Xiong H, Xu F and Zou Y, 2016. Characterizing $\mathrm{N}$ uptake and use efficiency in rice as influenced by environments. Plant Prod. Sci. 19(1): 96-104.

Malik MS, Abbasi MK and Rahim N, 2000. Laboratory study of physical-chemical characteristics and the nutrient status of soils collected from Rawalakot Azad Jammu and Kashmir. Pak. J. Biol. Sci. 3: 2082-2086.

Mingorance MD, Barahona E and Fernándes-Gálvez J, 2007. Guidelines for improving organic carbon recovery by wet oxidation method. Chemosphere, 68: 409-413.

Mozafar A, 2008. Nitrogen fertilizers and the amount of vitamins in plants: A review. J. Plant Nutr. 16(12): 2479-2506.

Nieder R, Benbi DK and Reichl FX, 2018. Soil-Borne Gases and Their Influence on Environment and Human Health. Soil Components and Human Health. Springer Netherlands, Dordrecht. pp. 179221.

Nweke IA and Nsoanya LN, 2015. Effect of cow dung and urea fertilization on soil properties, growth and yield of cucumber (Cucumis sativus L.). J. Agric. Ecol. Res. Int. 3: 81-88.

Okoli PSO and Nweke IA, 2015. Effect of poultry manure and mineral fertilizer on the growth performance and quality of cucumber fruits. J. Exp. Biol. Agric. Sci. 3(4): 362-367.

Oldroyd GED and Leyser O, 2020. A plant's diet, surviving in a variable nutrient environment. Science. 368(6486): eaba0196.

Onwu AC, Abubakar JR and Unah PO, 2014. Effect of poultry manure on growth, yield of okra and soil properties in Makurdi, North Central Nigeria. Int. J. Agric. Food Sci. 4 (1): 9-12.

Onwu AC, Ayuba SA and Ali A, 2008. The effect of organic manure on the growth and yield of castor plant (Ricinus Cumunis). J. Sustain. Develop. Agric. Environ. 3(2): 64-70. 
Panwar NR, Ramesh P, Singh AB and Ramana S, 2010. Influence of organic, chemical, and integrated management practices on soil organic carbon and soil nutrient status under semi-arid tropical conditions in central India. Commun. Soil Sci. Plant Anal. 41: 1073-1083.

Petersen J, Thomsen IK, Mattsson L, Hansen EM and Christensen BT, 2012. Estimating the crop response to fertilizer nitrogen residues in long-continued field experiments. Nut. Cycling Agroecosys. 93(1): 1-12.

Pradeepkumar T, Bonny BP, Midhila R, John J, Divya MR and Roch CV, 2017. Effect of organic and inorganic nutrient sources on the yield of selected tropical vegetables. Sci. Hort. 224: 84-92.

Quansah GW, 2010. Effect of organic and inorganic fertilizers and their combinations on the growth and yield of maize in the semi-deciduous forest zone of Ghana. M.Sc. thesis. Department of Crop and Soil Sciences, Kwame Nkrumah University of Science and Technology, Kumasi, Ghana.

Rajasree R, Sibi P, Francis F and William H, 2016. Phytochemicals of Cucurbitaceae family-A review. Int. J. Pharma. Phytochem. Res. 8(1): 113123.

Ramesh P, Panwar NR, Singh AB, Ramana S and Rao AS, 2009. Impact of organic-manure combinations on the productivity and soil quality in different cropping systems in central India. J. Plant Nutr. Soil Sci. 172: 577-585.

Rolnik A and Olas B, 2020. Vegetables from Cucurbitaceae family and their products; positive effect on human health. Nutrition, 78: 110788.

Sáez-Plaza P, Navas MJ, Wybraniec S, Michalowski T and Asuero AG, 2013. An overview of Kjeldahl method of nitrogen determination. Part II. Sample preparation, working scale, instrumental finish and quality control. Crit. Rev. Anal. Chem. 43: 224-272.

Salim N and Raza A, 2020. Nutrient use efficiency (NUE) for sustainable wheat production: a review. J. Plant Nutr. 43(2): 297-315.

Singh NP, Bhardwaj A, Kumar A and Singh KM, 2004.
Modern technology on vegetable production. Int. Book Distributing Co. India. pp. 228-231.

Teng Z, Haute SV, Zhou B, Hapeman CJ, Millner PD, Wang Q and Luo Y, 2018. Impacts and interaction of organic compounds with chlorine sanitizer in recirculated and reused produce processing water. PLoS ONE 13(12): e0208945.

Ye X, Ye Y, Chai R, Li J, Ma C, Li H, Xiong Q and Gao $\mathrm{H}, 2019$. The influence of a year-round tillage and residue management model on soil $\mathrm{N}$ fractions in a wheat-maize cropping system in central China. Sci. Rep. 9(1): 4767.

Zarei MJ, Kazemi N and Marzban A, 2019. Life cycle environmental impacts of cucumber and tomato production in open-field and greenhouse. J. Saudi Soc. Agric. Sci. 18(3): 249-255.

Zhang X, Davidson EA, Mauzerall DL, Searchinger TD, Dumas P and Shen Y, 2015. Managing nitrogen for sustainable development. Nature, 528(7580): 5159.

Žydelis R, Lazauskas S, Volungevičius J and Povilaitis $\mathrm{V}, 2019$. Effect of organic and mineral fertilizers on maize nitrogen nutrition indicators and grain yield. Zemdirbyste-Agriculture, 106(1): 15-20.

\section{Contribution of Authors}

Zahid N, Ahmed MJ, Hussain SJ \& Khaliq A: Conceptualized part of the research, performed the experiment, data collection, collation, analysis and manuscript write up

Tahir MM, Maqbool M \& Shah SZA: Performed data analysis, and helped in writing and editing of manuscript

Rehmani MIA: Helped in editing of manuscript 